\title{
TABU JEZZYKOWE I EUFEMIZACJA A WARIANTYWNOŚĆ TEKSTÓW UKRAIŃSKICH LUDOWYCH PIEŚNI OBSCENICZNYCH
}

\author{
JADWIGA STĘPNIK-SZEPTYŃSKA \\ Uniwersytet Jagielloński, Kraków - Polska \\ jadwiga.stepnik@uj.edu.pl; ORCID: 0000-0001-9890-6027

\section{МОВНЕ ТАБУ І ЕВФЕМІЗАЦІЯ ТА ВАРІАНТНІСТЬ ТЕКСТІВ УКРАЇНСЬКИХ СОРОМІЦЬКИХ ПІСЕНЬ}

\section{ЯДВІГА СТЕМПНІК-ШЕПТИНСЬКА}

Ягеллонський університет, Краків - Польща

\begin{abstract}
АНОТАЦІЯ. У статті розглянуто проблему методології дослідження евфемізмів (як відповіді на вплив мовного табу) в текстах українських народних сороміцьких пісень. У польській науковій літературі рекомендується досліджувати евфемізми у народних піснях шляхом порівняння варіантів пісень, які записані в різних місцях і в різний час. На основі аналізу текстів, опублікованих у двох збірниках сороміцьких пісень, виявилось, що цей спосіб дослідження евфемізмів не дозволяє ствердити, який був напрямок змін; чи відбулася евфемізація, чи вульгаризація тексту. У висновках запропоновано використання згаданого методу для аналізу оригінальних текстів у рукописах або варіантів, які відомі одному виконавцеві чи групі, напр., мешканцям одного села. Щоб реалізувати друге з названих завдань, необхідно було б провести польові дослідження.
\end{abstract}

Ключові слова: евфемізм, мовне табу, варіант, сороміцькі пісні, методологія 


\title{
TABOO LANGUAGE AND EUPHEMISMS IN TEXTUAL VARIANTS OF UKRAINIAN OBSCENE FOLK SONGS
}

\author{
JADWIGA STĘPNIK-SZEPTYŃSKA \\ Jagiellonian University, Cracow - Poland
}

\begin{abstract}
This article investigates some methodological issues in research on euphemisms (resulting from taboo language) in textual variants of Ukrainian obscene folk songs. In the Polish scholarly literature, it has been suggested that euphemisms can be identified by comparing texts recorded in different territories and time. It is argued in this paper, on the basis of a comparative analysis of texts published in two collections of obscene songs, that using this method does not allow to determine the direction of changes in the texts. One cannot tell for sure whether the phrases became vulgarized or euphemized. The conclusions contain a suggestion to investigate euphemisms in obscene songs by applying the method in question to original manuscripts or parallel variants of songs known to a single performer or community, e.g. the inhabitants of one village. In order to achieve the latter aim it would be necessary to carry out fieldwork.
\end{abstract}

Keywords: euphemism, taboo language, variant, Ukrainian obscene folk songs, methodology

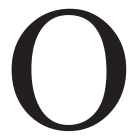
zjawisku tabu językowego i jego rozumieniu pisano w polskiej ${ }^{1}$ nauce już wielokrotnie [zob. m.in. Dąbrowska 1993; Krawczyk-Tyrpa 2001; Widłak 1968, Leszczyński 1988]. Szczegółowego przeglądu definicji tego pojęcia, zarówno słownikowych, jak i formułowanych przez poszczególnych badaczy, dokonała swego czasu A. Dąbrowska [Dąbrowska 1993: 14-32]. Biorąc pod uwagę dotychczasowe ustalenia lingwistów, można uznać, że tabu językowe to przejaw ogólnego zjawiska w sferze języka, przybierający postać nieformalnego zakazu pewnych zachowań językowych.

Tradycyjnie w polskim językoznawstwie wyróżnia się tabu tematyczne oznaczające zakaz wypowiadania się na określone tematy - oraz wyrazowe ograniczające użycie konkretnych słów [Krawczyk-Tyrpa 2001: 14]. Przyczyny tabu językowego ${ }^{2}$ mają charakter pozalingwistyczny i są zmienne w czasie i przestrzeni, tak jak samo zjawisko. Do sfer oddziaływania tabu językowego najczęściej zalicza się śmierć, erotykę, choroby, fizjologię i anatomię człowieka (nazwy niektórych części ciała i procesów fizjologicznych), a także nazwy bóstw,

${ }^{1} \mathrm{Na}$ gruncie ukraińskim wśród prac dotyczących tabu językowego warto wymienić słownik Українська мова без табу. Словник нецензурної лексики та ї̈ відповідників. Обсценізми, евфемізми, сексуалізми poprzedzony dość obszernym wstępem, w którym zawarto również rozważania ogólne dotyczące tabu językowego i eufemizmów [Stavytska 2008: 11-70].

${ }^{2}$ S. Widłak jest autorem szczegółowej i często wykorzystywanej klasyfikacji przyczyn tabu językowego i dziedzin jego oddziaływania [Widłak 1968: 10-11]. 
diabła oraz niektórych zwierząt. Zakaz językowy dotyczący trzech ostatnich dziedzin we współczesnych społecznościach ma bardzo ograniczony charakter, można zaryzykować stwierdzenie, że występuje w postaci szczątkowej. Jego oddziaływanie związane jest przede wszystkim ze społecznościami prymitywnymi, w których żywa była magia językowa polegająca na utożsamianiu słowa z jego desygnatem. Obszarami wpływów tabu językowego są także polityka oraz zagadnienia związane ze statusem społecznym i finansowym. Współcześnie za nowe przejawy działania tabu językowego uznaje się także kwestie związane z poprawnością politycznąa ${ }^{3}$.

Skutki oddziaływania tabu na poziomie języka mogą mieć dwojaki charakter-milczenie lub zamiana niepożądanych wyrazów czy określeń na inne, mające pozytywny bądź przynajmniej neutralny wydźwięk $k^{4}$. Badacze problematyki tabu językowego i będących konsekwencją jego oddziaływania eufemizmów formułują, podobnie jak w przypadku samego zjawiska tabu, wiele definicji eufemizmu [por. Widłak 2008; Dąbrowska 1993; Engelking 1984; Krawczyk-Tyrpa 2001]. Najczęściej zwraca się w nich uwagę na zastępczość eufemizmu w stosunku do innych jednostek leksykalnych, które z jakichś powodów nie powinny być w danym kontekście zastosowane.

Zdaniem M. Grochowskiego, eufemizmy mają relatywny charakter. Daną jednostkę można uznać za eufemizm na podstawie porównania z inną. Autor podkreśla, że taki zabieg i jego konsekwencja w postaci sklasyfikowania danego obiektu językowego jako eufemizmu jest zadaniem trudnym, zależnym od wielu czynników i często wymagającym odwołania się do subiektywnej oceny ze strony badacza [Grochowski 2002: 23-24].

\section{Metoda i cel}

Do porównywania dwóch jednostek w celu uznania jednej z nich za eufemizm odwołuje się także A. Tyrpa. W artykule dotyczącym eufemizmów w pieśniach ludowych autorka proponuje kilka metod badania określeń zastępczych w owych pieśniach [Tyrpa 2008: 242]. Jedną z nich ${ }^{5}$ jest porównywanie wariantów jednej

${ }^{3} \mathrm{Na}$ ten temat pisze m.in. A. Dąbrowska [Dąbrowska 2008: 173-196]; teksty dotyczące zmian w obszarach współcześnie podlegających tabu można znaleźć również w tomie Tabu w procesie globalizacji kultury, Lublin 2016 (Tabu w procesie globalizacji kultury pod redakcją A. Małyski i K. Sobstyl, Lublin 2016).

${ }^{4}$ Oprócz tego w celach eufemizacji mogą być stosowane także dodatkowe środki, np. w postaci modulacji głosu czy mimiki, towarzyszące wypowiadanym słowom, a na poziomie tekstu pisanego znaki takie jak cudzysłów czy wielokropek, a ostatnio także zyskujące popularność gwiazdki (*).

${ }^{5}$ Obok analizy tekstu pieśni opartej na znajomości gwary oraz analizy tekstu pieśni jako całości [Tyrpa 2008: 242]. 
pieśni zapisanych w różnym miejscu i czasie ${ }^{6}$. Ten sposób analizy eufemizmów pieśniowych, o ile mi wiadomo, nie był do tej pory wykorzystywany przez badaczy. Warto więc pokusić się o sprawdzenie jego efektywności. Taki cel stawiam sobie w niniejszym artykule, a wspomnianą metodę zastosuję do badania reprezentatywnego zbioru pieśni ludowych, w których obecna jest tematyka obsceniczna.

Pobocznym motywem wyboru metody była potrzeba weryfikacji, formułowanego przez niektórych badaczy ${ }^{7}$, twierdzenia o jednostkowości i przypadkowości tekstów obscenicznych w ukraińskim folklorze. Istnienie wariantów danego utworu wskazuje na fakt zaakceptowania go przez społeczność, w której funkcjonował. Ową akceptację badacze folkloru uznają za warunek konieczny „przetrwania” określonego tekstu, jeśli jest on bowiem „,z jakichś przyczyn nie do przyjęcia dla społeczności [...] jest skazany na zagładę” [Bogatyriew, Jakobson 1979: 306]. W innym miejscu czytamy:

Кожен твір у процесі побутування, передаючись з уст в уста, проходить своєрідне шліфування з точки зору народного ставлення до моралі, життєвих засад. Навіть коли окремі виконавці вносять свої зміни, відповідно до власних поглядів і уявлень, то в народі зберігаються лише ті твори чи їх елементи, що повністю відповідають загальному світобаченню [Лановик М., Лановик 3. 2006: 23].

Liczba wariantów w materiale poddanym przeze mnie analizie nie jest imponująca, jeśli weźmiemy pod uwagę ogólną liczbę pieśni obscenicznych opublikowanych w zbiorach wykorzystanych jako źródło. Wydaje się jednak, że taka sytuacja, na co zwracają uwagę również inni badacze [m.in. Bracki 2009; Krasykov 2003; Tyrpa 2008; Sulyma 2001], nie wynika z braku akceptacji danego tekstu przez społeczność, a z kilku innych powodów. Należy pamiętać, że ze względu na specyfikę folkloru obscenicznego mogły istnieć trudności w rejestrowaniu tego typu tekstów leżące zarówno po stronie zbieraczy folkloru, jak i informatorów, a w kolejnym etapie także jego wydawców. Każda z wymienionych osób mogła podlegać (i nierzadko podlegała) obyczajowym ograniczeniom powodującym niechęć lub odmowę przekazywania pewnych treści wyrażonych w mniej lub bardziej bezpośredni sposób. Anna Tyrpa podaje przykład romantyków, którzy, jak pisze autorka, do pieśni erotycznych „mieli stosunek niechętny, gorszyli się [...] W związku z tym, albo wcale nie rejestrowali utworów uznanych za rozpustne, albo poddawali je zabiegom łagodzącym zbyt ostro wyrażone treści” [Tyrpa 2008: 240]. Badaczka przytacza również wypowiedź księdza Bernarda Sychty, który podczas pracy nad Stownikiem gwar kaszubskich na tle kultury ludowej spotkał się ze stwierdzeniem

\footnotetext{
${ }^{6}$ A. Tyrpa wskazuje, że zwolennikiem tej metody, jako najwłaściwszej, jest również J. Bartmiński [Tyrpa 2008: 242].

${ }^{7}$ M.in. M. Lesiuk w pracy Еротизм в українському пісенному фольклорі: лінгвістичний асnекm pisze, że pieśni, w których pojawiają się określenia o charakterze wulgarnym, obscenicznym funkcjonują jako wyjątek na tle ukraińskiej twórczości ludowej [Лесюк 2010: 44].
} 
informatorek, że poruszają pewne treści w jego obecności tylko dlatego, że jest księdzem. Innemu mężczyźnie „by o tym nie gadały” [Krawczyk-Tyrpa 2001:25].

Swoista cenzura w zakresie publikacji tekstów pieśni obscenicznych dotyczyła również folkloru ukraińskiego. W poszczególnych wydaniach tekstów można napotkać wersje pieśni obscenicznych z usuniętymi wyrazami lub całymi fragmentami. Niekiedy we wstępach do opracowań pojawiają się wprost stwierdzenia o eliminacji pewnych utworów lub ich części ze względu na ich „nieprzyzwoitą" treść [Стемпнік-Шептинська 2015: 37-38]. Kolejnym czynnikiem wpływającym na małą liczbę wariantów pieśni obscenicznych, i nie tylko, może być fakt, na który zwrócił uwagę A. Bracki, a mianowicie tendencja do ujednolicania tekstów folkloru ukraińskiego ze względu na specyficzny stosunek Ukraińców do tej formy twórczości, polegający na traktowaniu jej jak istotnego elementu tożsamości narodowej [Bracki 2009: 11].

\section{Pojęcie wariantu w folklorze}

Badacze (m.in. J. Bartmiński, R. Sulima, K. Moszyński, P. Bogatyriew, R. Jakobson, M. Lanovyk, Z. Lanovyk, I. Rusnak, N. Szumada, S. Yermolenko) zajmujący się folklorem, rozumianym jako ustna twórczości ludowa, wskazują na kilka charakterystycznych cech folkloru odróżniających go od literatury pisanej. Obok ustnej formy funkcjonowania, czyli współtworzenia go przez określoną społecznośś ${ }^{8}$, anonimowości autora oraz synkretyzmu form i gatunków, wymienia się także wariantywność.

Według Stownika folkloru polskiego wariant to „każdorazowa postać zjawiska folklorystycznego, podania, pieśni, bajki, przysłowia, zagadki” zawierająca „drobne zmiany, odchylenia redakcyjne" wprowadzane przez poszczególnych wykonawców utworów ludowych [Słownik folkloru polskiego 1965: 427]. Istnienie wariantów tekstów folkloru wynika z ustnej formy jego funkcjonowania. Wykonawca utworu ludowego, reprodukując znany mu wzorzec (inwariant), wprowadza w nim pewne modyfikacje, które mogą wynikać z różnych przyczyn. Należą do nich kontekst wykonania, fantazja i talent wykonawcy, pochodzenie odtwórcy z innego niż utwór regionu czy bardziej prozaiczny powód - niedoskonała pamięć wykonawcy. Ukraińska badaczka S. Yermolenko w odniesieniu do pieśni ludowych stwierdza, że ich warianty mogą się różnić pod względem leksykalnym, słowotwórczym i leksykalno-syntaktycznym, zachowując jednocześnie logiczną treści utworu [Срмоленко 1987: 67].

\footnotetext{
${ }^{8}$ Ustność i kolektywność folkloru, zdaniem niektórych badaczy, zbliżają go do sposobu funkcjonowania języka. Relację między tekstem (inwariantem mającym charakter wzorca, schematu) a jego aktualizacją (wariantami powstającymi w rezultacie kolejnych wykonań) porównywano do relacji langue i parole. Więcej o tym [Bogatyriew, Jakobson 1979: 306].
} 


\section{Źródła i material}

$\mathrm{Z}$ uwagi na tematykę do analizy pod kątem oddziaływania tabu językowego wybrałam warianty ukraińskich pieśni obscenicznych zawarte w dwóch wydanych w XXI wieku zbiorach - Бандурка. Українські сороміџькі пісні, opublikowanym w Kijowie w 2001 roku oraz Украӥнські сороміцькі пісні, wydanym w Charkowie w 2003 roku. W obydwu wydaniach znalazły się pieśni zapisane przede wszystkim w XIX, a także częściowo XX wieku.

Powyższy wybór może spotkać się z zarzutem, iż w pieśniach zawierających treści obsceniczne tabu nie działa. Tak jest rzeczywiście, jeśli chodzi o jeden z aspektów oddziaływania tabu językowego - tabu tematyczne. Wybrane pieśni dotyczą seksualności, erotyki, częściowo także fizjologii, które tradycyjnie uznawane są za obszar objęty działaniem tabu (nie tylko w sferze języka). Jednak nie wszystkie pieśni podejmujące wspomniane zagadnienia łamią jednocześnie zakaz używania pewnego słownictwa (szczególnie o charakterze wulgarnym). W części utworów pojawiają się określenia o pozornie neutralnym, „niewinnym” znaczeniu, których właściwa treść ujawnia się dopiero w kontekście. To właśnie te teksty i ich „niecenzuralne” odpowiedniki, warianty są głównym przedmiotem mojego zainteresowania. Pieśni obsceniczne należą do tzw. folkloru obscenicznego wyróżnianego z uwagi na treść utworów (ukr. сороміцький9 фольклор, ukr. сором 'wstyd'). Do tej kategorii zalicza się obok pieśni także bajki, anegdoty, przyśpiewki. Obsceniczne motywy można spotkać także w tzw. folklorze dziecięcym (piosenki, zagadki).

Większość analizowanych przeze mnie utworów to pieśni weselne - jeden z typów pieśni obrzędowych rodzinnych. Taki wybór motywowany był m.in. doniosłością roli kontekstu we właściwej interpretacji tekstów folkloru. Zdaniem niektórych badaczy, wiedza na temat konsytuacji towarzyszącej wykonywaniu pieśni jest niezbędna do prawidłowego zrozumienia tekstu [Ługowska 1990: 176-179, Hernas za: Ługowska 1990: 186]. Jerzy Bartmiński zwraca również uwagę na znajomość cech charakteryzujących dany gatunek jako element decydujący o jego właściwej interpretacji [Bartmiński 1990: 15].

\section{Warianty pieśni poddane analizie}

Analiza zebranego materiału pozwala na wyodrębnienie kilku typów wariantów, w zależności od tego, jaki element tekstu podlega zmianie. Pierwszy typ de facto nie ma wielkiego znaczenia w badaniach nad tabu językowym, ale warto

\footnotetext{
${ }^{9}$ Ustność i kolektywność folkloru, zdaniem niektórych badaczy, zbliżają go do sposobu funkcjonowania języka. Relację między tekstem (inwariantem mającym charakter wzorca, schematu) a jego aktualizacją (wariantami powstającymi w rezultacie kolejnych wykonań) porównywano do relacji langue i parole. Więcej o tym [Bogatyriew, Jakobson 1979: 306].
} 
o nim wspomnieć ze względu na istnienie pewnych potencjalnych możliwości dla tych badań (dokładniej o tym zob. niżej). Do tej grupy należą teksty, w których zmieniają się elementy niezwiązane $\mathrm{z}$ treściami tabu. To oznacza, że określenia wulgarne $\mathrm{i} /$ lub obsceniczne oraz określenia o charakterze eufemistycznym ${ }^{10}$ pozostają w niezmienionej postaci, np.:

1. Сидить ведмідь на стерні, / Штани зашиває, / Стерня його в сраку коле, / А він її лас $[\mathrm{B}, 2 / 66]^{11}$.

Сидить козак на стерні / Та штани латає: / Стерня його в сракуколе, / А він штани лає! [B, 84/156].

2. Продрав котко стелю / Да впав на постелю: / Поти качався, / Поти валявся, / Поки тій Марушці / Між ніженьки вбрався! [В, 27/37]. Продрав котик стелю, / Ta впав на постелю: / Поти качався, / Поти валявся, / Поки тій Марусеньці / Між ніженьки вбрався! [В, 25/142-143].

W powyższych przykładach zaznaczyłam elementy, które różnią podane warianty, a także fragmenty związane ze sferą tabu ${ }^{12}$. Na uwagę zasługuje pierwszy z podanych przykładów, $w$ którym zmianie w poszczególnych wariantach podlegają m.in. nazwy wykonawcy czynności (ведмідь - козак). Taka zmiana w pewnych okolicznościach mogłaby mieć znaczenie dla badań nad tabu językowym. Chodzi mianowicie o potencjalną sytuację, gdy w jednym wariancie pojawia się nazwa zwierzęcia i słowo, które odnosi się do zwierząt (np. morda) i ma neutralny wydźwięk, a w innym zamiast nazwy zwierzęcia pojawia się nazwa osoby. Wówczas następuje zmiana zabarwienia emocjonalnego wyrażenia z neutralnego na potoczne albo nawet obraźliwe lub wulgarne. W tekstach poddanych przeze mnie analizie nie było tego typu przykładów, ale nie można jednoznacznie wykluczyć ich istnienia.

Do drugiego typu wariantów należą teksty, w których znaczenie tabu nie jest wyrażone wprost, a zmianie, obok fragmentów niezwiązanych z problematyką tabu, podlegają także różnego rodzaju określenia o charakterze eufemistycznym, np.:

\section{3. Сиував павук стелю / Та впав на постелю. / Де Маруся спала- / Там} роженька впала, / Червона калина процвітала! [B, 42/146-147].

${ }^{10}$ Określenie сороміцький pochodzi z obrzędowości weselnej. Ma ono dwa zakresy - wąski i szeroki. Pierwszy związany jest z odbiorem pewnych treści przez samych wykonawców folkloru. Za wstydliwe uznawali oni pieśni, w których była mowa wprost o genitaliach, akcie seksualnym i innych przejawach seksualności człowieka. Natomiast w szerokim rozumieniu сороміцьккий to tyle co erotyczny, którego nieprzyzwoita treść może być ukryta [Красиков 2003: 11].

${ }^{11}$ Tego określenia używam w stosunku do słów i wyrażeń, które przekazują daną treść w sposób neutralny lub pozytywnie wartościujący, nie wiadomo natomiast, czy mają charakter zastępczy w stosunku do określeń wulgarnych/obscenicznych użytych w tekstach wariantywnych.

${ }^{12}$ Litera w nawiasie jest skrótem źródła (B - Бандурка..., U - Українські сороміцькі пісні), potem podany jest numer pieśni w zbiorze, a po ukośniku strona. 
Прокрутив павук стелю / Да й впав на постелю; / Де Марися спала, / Там калинонька стала [U, 184/69], [B, 28/78].

4. У Києві на дзвониці / Чернець лежить на черниці. / Та так чернець спасається, / Аж дзвіниия хитається. / - Що ти робии, ченче? /- Cпасаюся, серие: / Всередину гріхи пхаю, / Щоб не вийшла душа з раю [В, 5/138]. У Києві на дзвониц і / Чернець лежить на черниці. / Та так чернець спасається, / Аж дзвіниия хитається. / - Що ти робиш, ченче? / - Cnaсаюся, серие: / „Сповідаю, причащаю, / Всередину гріхи запущаю!” $[\mathrm{B}, 5 / 138$, wariant $]$.

Warto zwrócić uwagę na drugi z powyższych przykładów (4). Wykorzystanie tematyki religijnej dla wyrażenia treści erotycznych może szokować.

$\mathrm{W}$ analizowanym materiale odnotowano również teksty, których warianty różnią się słowami wulgarnymi i obscenicznymi:

5. Старша свашка цицькою / Порося вбила, / На череві осмалила, / На сраці попарила / I на стіл поставила! [U, 102/51].

Старша свашка цицькою / Порося вбила, / На череві осмалила, / На пизді попарила / I на стіл поставила! [U, 102/51, wariant w przypisie].

6. Що ие за приданки, / Що не побили лавки, / Не підняли гузиці, / Не звалили і полиці [U, 238/83].

Що ие за приданки, / Що не вломили лавки! / Не зробили славки. / Пиздами потрусили / Та й на лаву посадили [U, 239/83].

Tego typu przykłady mogą świadczyć o tym, że łamanie tabu językowego nie jest zjawiskiem wyjątkowym w ukraińskim folklorze pieśniowym.

Ostatni typ badanych tekstów stanowią warianty, w których znaczenia tabu wyrażone są za pomocą określeń o różnym zabarwieniu stylistycznym. Ta grupa odgrywa najistotniejszą rolę w badaniach eufemizmów w tekstach pieśni. Poniżej podaję kilka przykładów wariantów tej grupy:

7. А) Гончар, мате, гончар, мате, / Треба йому трохи дати: / Сюди тер, туди тер, / Тай наробив макітер [U, 224/79].

В) Гончар, гончар, гончар, мате, / Треба йому поцьки дати; / За мисочку черешень / То давала б увесь день [U, 225/79].

8. А) Під сосною спала, / Шишка в [пизду] впала. / Долотом довбав-не видовбав, / Свердлом вертів - не вивертів; / Всадив кишку - вийнав шишку [B, 40/81].

В) Під сосною спала, / Шишка між ноги впала. / Свердлом вертів - / Да не вивертів; / Долотом довбав - / Да не видовбав; / Як упустив кишку - / Витяг з дірки шишку [В,29/37] [U, 194/71]. 
С) Під сосною спала, / Шиика в пизду впала: / Свердлом вертів, / Да не вивертів; / Долотом довбав, / Да не видовбав; / Як упустив кишку - / Витяг з пизди шиику! [B, 49/148].

9. А) Заганяйте квочку в бочку, / А курчата в вершу; / Признавайся, Марусю, / Кому давала спершу? / Давала Хомі, / Ще буде і тобі, / Давала попові, / Давала піддячему, / Ще й по-собачому [U, 382/122-123].

В) Заганяйте квочку в бочку, / А курчата в вершу; / Признавайся, Марусю, / Комудавала спершу? / - Давала Хомі. / Ще буде і тобі; / Давала попові, / Давала дякові, / Давала піддячому - / Ще й по-собачому!... [B, 47/147].

С) Заганяйте квочку в бочку, / А курчата в вершу. / Признавайся, Марусенько: / Хтоо пошморгав спершу? [В, 46/147].

D) Заганяла квочку у бочку, / А курята у вершу. / Признавайся, Галочко, / Кому давала пизди зпершу: / Чі попові, / Чі дякові, / Чі піддячому, / А чі хуєві собачому! [U, 383/123].

W przytoczonych wyżej fragmentach pieśni wyraźnie widać różnicę w sposobie wyrażania danego znaczenia tabu - od użycia określeń wulgarnych i obscenicznych do wyrażeń łagodniejszych, przybierających różną formę. Pojawia się jednak problem z określeniem kierunku zmian - nie sposób stwierdzić na pewno, czy mamy do czynienia z eufemizacją, czy wulgaryzacją tekstu ${ }^{13}$. Aby tego dokonać, należałoby odnaleźć pierwotny modelowy utwór, który posłużył poszczególnym wykonawcom za wzór. Niestety jest to zadanie bardzo trudne, o ile w ogóle wykonalne. Wątpliwości co do tego wyraził także J. Bartmiński, próbując ustalić granice „zbioru tekstów, które mogłyby uchodzić za warianty jednego utworu” [Bartmiński 1990: 135]. Badacz stwierdził, że „brak tym granicom ostrości, tj. jednoznacznego powiązania konkretnych wykonań z jednym utworem jako modelem" [Bartmiński 1990: 135].

Z uwagi na fakt, że materiał do analizy w niniejszym artykule stanowią opublikowane teksty pieśni obscenicznych, co do których wydawcy nie podają, niestety, w wielu przypadkach miejsca i daty zapisu (znamy wiek zapisu - XIX i XX), ustalenie pierwowzoru w celu stwierdzenia kierunku zmian dotyczących leksyki z zakresu tabu językowego praktycznie nie jest możliwe na podstawie tych przesłanek. Pamiętać jednak należy, że i one nie są gwarantem dotarcia do inwariantu. Data i miejsce zapisania utworu nie muszą pokrywać się (i często tak właśnie jest) z datą i miejscem jego powstania. Wynika to $\mathrm{z}$ funkcjonowania tekstów folkloru w formie ustnej oraz, zwłaszcza w przypadku pieśni, z ich wędrownego charakteru. Stosunek chronologiczny poszczególnych wariantów można ustalać również na podstawie innych przesłanek, takich jak np. struktura

\footnotetext{
13 Ten sam sposób oznaczania zastosowano we wszystkich przytoczonych przykładach.
} 
tekstu (rym i rytm) czy semantyka (spójność motywów) ${ }^{14}$. W badanym zbiorze odnotowano kilka tekstów, co do których można domniemywać, kierując się wyżej wymienionym typem kryteriów, czy mamy do czynienia z ich eufemizacją, czy odwrotnie - wulgaryzacją.

W odniesieniu do przykładu 7 na podstawie analizy liczby sylab w poszczególnych wersach (wariant A: 8/8/6/7; B: 8/8/7/7) można zaryzykować twierdzenie, że wariant A jest wtórną, zeufemizowaną wersją pieśni B ze względu na mniej regularny rytm. Z kolei, biorąc pod uwagę to samo kryterium (rytm), wydaje się, że w wariancie 9D mamy do czynienia z wulgaryzacją (Кому давала спершу - Кому давала пизди зпершу; Давала піддячему, / Ще й по-собачому - Чі піддячому, / А чі хуєві собачому).

Podobne przykłady jak te omówione powyżej stanowią większość w analizowanym przeze mnie zbiorze pieśni. Nie udało się odnaleźć tekstów wariantywnych, co do których istniałyby wyraźne i jednoznaczne przesłanki świadczące o eufemizacji lub wulgaryzacji. Jak słusznie zauważył M. Grochowski (o czym już pisałam), klasyfikowanie danej jednostki językowej jako eufemizmu zawsze jest obarczone pewną dozą subiektywizmu ze strony badacza [Grochowski 2002: 23-24]. Nie inaczej dzieje się w przypadku analizy określeń ze sfery tabu językowego w pieśniach ludowych, co pokazują powyższe przykłady.

Warto zwrócić uwagę, że w zbiorze Бандурка w części pieśni niektóre wyrazy, w tym słowa wulgarne i obsceniczne, ujęte są w nawias kwadratowy (przykład 8A). Użycie tego znaku można interpretować na wiele sposobów, także jako zabieg sygnalizujący wyraz, który z jakiegoś powodu można lub nawet należy pominąć albo zastąpić innym, a więc także słowo tabu. Niestety, rola i pochodzenie omawianego znaku graficznego we wspomnianym zbiorze są niejasne. Wydawca nie wskazuje na jego funkcję, nie podaje również, czy ów znak został wprowadzony przez niego, czy też występował w rękopisie.

$\mathrm{Z}$ powyższych uwag wynika, że zastosowanie metody badania eufemizmów w pieśniach, polegającej na porównywaniu wariantów zapisanych w różnym miejscu i czasie, nie daje oczekiwanych efektów w przypadku analizy wybranych przeze mnie tekstów opublikowanych. Być może lepsze rezultaty dałoby się osiągnąć, korzystając z rękopisów ${ }^{15}$, które są wolne od ingerencji wydawców, choć nie zawsze pozbawione zmian ze strony samych autorów zapisu. Te ostatnie można jednak w rękopisie prześledzić.

Alternatywą dla wykorzystania weryfikowanej metody byłaby analiza wariantów znanych jednemu wykonawcy lub szerzej - jednej grupie, np. mieszkańcom

${ }^{14}$ Pomijam kwestie związane z melicznością pieśni, jako że obiektem badania są teksty bez zapisu melodii.

${ }^{15} \mathrm{Na}$ ten problem, związany z proponowaną przez siebie metodą, zwraca również uwagę A. Tyrpa [Tyrpa 2008:246]. 
jednej wsi ${ }^{16}$. Takie rozwiązanie wymagałoby przeprowadzenia badań terenowych i dokonania własnych zapisów tekstów wariantywnych, co jest dziś dodatkowo utrudnione ze względu na zanik folkloru tradycyjnego. Nie znaczy to oczywiście, że nie warto podjąć takiego wysiłku.

\section{Wykaz wykorzystanej literatury}

Bartmiński J., Folklor - Język - Poetyka, Wrocław: Zakład Narodowy im. Ossolińskich, 1990. Bartmiński J., Dialektolog o tabu językowym, [w:] „Etnolingwistyka” 2004, t. 16, s. 350-352.

Bogatyriew P., Jakobson R., Folklor jako swoista forma twórczości, [w:] Semiotyka kultury ludowej, red. P. Bogatyriew, Warszawa: Państwowy Instytut Wydawniczy, 1979, s. 305-319.

Bracki A., Językowy obraz świata w tekstach słowiańskich pieśni ludowych, Gdańsk: Wydawnictwo Uniwersytetu Gdańskiego, 2009.

Dąbrowska A., Eufemizmy współczesnego języka polskiego, Wrocław: Wydawnictwo Uniwersytetu Wrocławskiego, 1993.

Dąbrowska A., Zmiany obszarów podlegających tabu we współczesnej kulturze, [w:] „Język a kultura", 20: Tom jubileuszowy, red. A. Dąbrowska, Wrocław: Wydawnictwo Uniwersytetu Wrocławskiego, 2008, s. 173-196.

Engelking A., Istota i ewolucja eufemizmów (na przykładzie zastępczych określeń śmierci), [w:] „Przegląd Humanistyczny”, 1984, nr 4, s. 115-129.

Grochowski M., Stownik polskich przekleństw i wulgaryzmów, Warszawa: Wydawnictwo Naukowe PWN, 2002.

Krawczyk-Tyrpa A., Tabu w dialektach polskich, Bydgoszcz: Wydawnictwo Akademii Bydgoskiej Kazimierza Wielkiego, 2001.

Leszczyński Z., Szkice o tabu językowym, Lublin: Redakcja Wydawnictw KUL, 1988.

Ługowska J., Rola kontekstu w procesie kształtowania się kulturowych znaczeń tekstów folkloru, [w:] „Tekst w kontekście. Zbiór studiów”, red. T. Dobrzyńska, Wrocław-Warszawa-Kraków: Zakład Narodowy im. Ossolińskich, 1990, s. 175-186.

Stownik folkloru polskiego, red. J. Krzyżanowski, Warszawa: Wiedza Powszechna, 1965.

Tabu w procesie globalizacji kultury, red. A. Małyska, K. Sobstyl, Lublin: Wydawnictwo UMCS, 2016.

Tyrpa A., O eufemizmach w pieśniach ludowych, [w:] „Tabu językowe i eufemizacja w dialektach słowiańskich", red. F. Czyżewski, A. Tyrpa, Lublin: Wydawnictwo UMCS, 2008, s. 239-250.

Widłak S., Zjawisko tabu językowego, [w:] „Lud” 1968, t. 52, s. 7-25.

Widłak S., Eufemizm i jego ,gramatyka stylistyczna”, [w:] „Językoznawstwo historyczne i typologiczne. W 100-lecie urodzin Profesora Tadeusza Milewskiego", red. L. Bednarczuk, Kraków: Polska Akademia Umiejętności, 2008, s. 351-358.

${ }^{16}$ Pomijam kwestie związane z melicznością pieśni, jako że obiektem badania są teksty bez zapisu melodii. 
Срмоленко С.Я., Фольклор і літературна мова, Київ: Наукова думка, 1987.

Красиков М., Таємничий дивосвіт украӥнського еросу, [в:] „Українські сороміцькі пісні”, ред. М. Красиков, Харків: „Фоліо”, 2003, с. 3-16.

Лесюк М., Еротизм в українському пісенному фольклорі: лінгвістичний аспект, Івано-Франківськ: Місто НВ, 2010.

Лановик М., Лановик 3., Українська усна народна творчість, Київ: „Знання-Прес”, 2006.

Руснак I.С., Украӥнський фольклор, Київ: Академія, 2010.

Ставицька Л., Украӥнська мова без табу. Словник нецензурної лексики та ї̈ відповідників. Обсиенізми, евфемізми, сексуалізми, Київ: Критика, 2008.

Стемпнік-Шептинська Я., Характеристика джерел і матеріалів для вивчення мовного табу в українських піснях, [w:] „Сучасні дослідження української культури”, Warszawa: Sowa sp. z o. о., 2015, s. 31-43.

Шумада Н.С., Поетична творчість украӥнського народу, [в:] „Закувала зозуленька. Антологія української народної творчості”, Київ: „Веселка”, 1989, s. 5-18.

\section{Wykaz wykorzystanej literatury [References]}

Bartmiński J., Folklor - Język - Poetyka [Folklore - Language - Poetics], Wrocław: Zakład Narodowy im. Ossolińskich, 1990.

Bartmiński J., Dialektolog o tabu językowym [A Dialectologist on Taboo Language], [w:] „Etnolingwistyka” 2004, t. 16, s. 350-352.

Bogatyriew P., Jakobson R., Folklor jako swoista forma twórczości [Folklore as a Special Form of Creation], [w:] „Semiotyka kultury ludowej”, red. P. Bogatyriew, Warszawa: Państwowy Instytut Wydawniczy, 1979, s. 305-319.

Bracki A., Językowy obraz świata w tekstach słowiańskich pieśni ludowych [The Linguistic Picture of the World in Texts of Slavic Folk Songs], Gdańsk: Wydawnictwo Uniwersytetu Gdańskiego, 2009.

Dąbrowska A., Eufemizmy współczesnego języka polskiego [Euphemisms of the Contemporary Polish Language], Wrocław: Wydawnictwo Uniwersytetu Wrocławskiego, 1993.

Dąbrowska A., Zmiany obszarów podlegajacych tabu we wspótczesnej kulturze [Changes in the Areas of the Contemporary Culture being Subject to Taboo], [w:] „Język a kultura”, 20: Tom jubileuszowy, red. A. Dąbrowska, Wrocław: Wydawnictwo Uniwersytetu Wrocławskiego, 2008, s. 173-196.

Engelking A., Istota i ewolucja eufemizmów (na przyktadzie zastępczych określeń śmierci)

[The Essence and Evolution of Euphemisms as Exemplified by Substitutive Designations of Death], [w:] „Przegląd Humanistyczny” 1984, nr 4, s. 115-129.

Grochowski M., Stownik polskich przekleństw i wulgaryzmów [Dictionary of Polish Swearwords and Vulgarisms], Warszawa: Wydawnictwo Naukowe PWN, 2002.

Krawczyk-Tyrpa A., Tabu w dialektach polskich [Taboo in Polish Dialects], Bydgoszcz: Wydawnictwo Akademii Bydgoskiej Kazimierza Wielkiego, 2001. 
Leszczyński Z., Szkice o tabu językowym [Sketches on Taboo Language], Lublin: Redakcja Wydawnictw KUL, 1988.

Ługowska J., Rola kontekstu w procesie kształtowania się kulturowych znaczeń tekstów folkloru

[The Role of Context in the Formation of Cultural Meanings of Folklore Texts], [w:] „Tekst w kontekście. Zbiór studiów”, red. T. Dobrzyńska, Wrocław-Warszawa-Kraków: Zakład Narodowy im. Ossolińskich, 1990, s. 175-186.

Stownik Folkloru Polskiego [Dictionary of Polish Folklore], red. J. Krzyżanowski, Warszawa: Wiedza Powszechna, 1965.

Tabu w procesie globalizacji kultury [Taboo in the Globalisation of Culture], red. A. Małyska, K. Sobstyl, Lublin: Wydawnictwo UMCS, 2016.

Tyrpa A., O eufemizmach w pieśniach ludowych [On Euphemisms in Folk Songs], [w:] „Tabu językowe i eufemizacja w dialektach słowiańskich”, red. F. Czyżewski, A. Tyrpa, Lublin: Wydawnictwo UMCS, 2008, s. 239-250.

Widłak S., Zjawisko tabu językowego [The Phenomenon of Taboo Language], [w:] „Lud” 1968, t. 52, s. 7-25.

Widłak S., Eufemizm i jego „,gramatyka stylistyczna” [Euphemisms and Their „Stylistic Grammar”], [w:] „Językoznawstwo historyczne i typologiczne. W 100 lecie urodzin Profesora Tadeusza Milewskiego", red. L. Bednarczuk, Kraków: Polska Akademia Umiejętności, 2008, s. 351-358.

Yermolenko S. Ya., Folklor i literaturna mova [Folklore and Literary Language], Київ: Наукова думка, 1987.

Krasykov M., Taiemnychyi dyvosvit ukrainskoho erosu [The Mysterious Wonderland of Ukrainian Eros], [v:] Ukrainski soromitski pisni, red. M. Krasykov, Kharkiv: „Фоліо” 2003, s. 3-16.

Lesiuk M., Erotyzm v ukrainskomu pisennomu folklori: linhvistychnyi aspekt [Eroticism in Ukrainian Folk Songs: the Linguistic Aspect], Ivano-Frankivsk: Мiсто HB, 2010.

Lanovyk M., Lanovyk Z., Ukrainska usna narodna tvorchist [Ukrainian Oral Folk Art], Kyiv: „Знання-Прес”, 2006.

Rusnak I., Ye., Ukrainskyi folklor [Ukrainian Folklore], Куіv: Академія, 2010.

Stavytska L., Ukrainska mova bez tabu. Slovnyk netsenzurnoi leksyky ta yii vidpovidnykiv. Obstsenizmy, evfemizmy, seksualizmy [Ukrainian language without taboos. Dictionary of obscene language and its equivalents. Obscenisms, euphemisms, sexualisms], Kyiv: Критика, 2008.

Stępnik-Szeptyńska J., Kharakterystyka dzherel i materialiv dlia vyvchennia movnoho tabu $v$ ukrainskykh pisniakh [Characterisation of Sources and Materials for Investigating Taboo Language in Ukrainian Songs], [v:] Suchasni doslidzhennia ukrainskoi kultury, Warszawa: Sowa sp. z o. o., 2015, s. 31-43.

Shumada N.S., Poetychna tvorchist ukrainskoho narodu [Poetry of the Ukrainian People], [v:] „Zakuvala zozulenka. Antolohiia ukrainskoi narodnoi tvorchosti”, Kуiv: „Веселка”, 1989, s. 5-18. 


\section{Wykaz wykorzystanych źródel}

Бандурка. Украӥнські сороміцьькі пісні, ред. М. Сулима, Київ: Дніпро, 2001.

Українські соромічькі пісні, ред. М.М. Красиков, Харків: „Фоліо”, 2003.

\section{Wykaz wykorzystanych źródel \\ [References]}

Bandurka. Ukrainski soromitski pisni [Bandurka. Ukrainian Obscene Songs], red. M. Sulyma, Kyiv: Dnipro, 2001.

Ukrainski soromitski pisni [Ukrainian Obscene Songs], red. M. Krasykov, Kharkiv: Folio, 2003. 